\title{
Internet Banking Espousal in Bangladesh: A Probing Study
}

\author{
Alim Al Ayub Ahmed", Md. Nur-E-Alam Siddique ${ }^{2}$ \\ ${ }^{1}$ Assistant Professor, Faculty of Business, ASA University Bangladesh \\ ${ }^{2}$ Senior Lecturer, Faculty of Business, ASA University Bangladesh
}

\begin{abstract}
Internet banking (IB) is a distinctive banking improvement with the intention of potentially can convert the monetary services scenery in budding nations such as Bangladesh. Nevertheless, due to the connected near to the ground acceptance rate, its full potential in deepening and extending banking services is yet to be realized, as a decisive group of customers is yet to be accessed. As a result, a improved thoughtful of why some banking customers agree to IB and others do not, alongside a recognition of the factors influencing this choice is expected to be of significant realistic as well as intellectual value. For this ground, the rationale of this learning was to explore the factors influencing the approval and practice patterns of IB among Bangladeshi customers. Using Rogers' IDT structure, data was composed by means of a self-completion questionnaire, in which some 249 banking clients participated. Findings propose perceptions of risk, lack of adequate support and training from banking institutions are some of the causes of non-usage. The implications of these conclusions are that banks possibly will centre extra concentration on cross-selling IB mutually with other financial commodities, as IB is hardly ever used in remoteness. Installing individual computers surrounded by branches in combination with campaigns and demonstrations might also get better rates of approval.
\end{abstract}

Keywords: Internet banking, isolated banking, retail economic services, Bangladesh

\section{INTRODUCTION}

The successful introduction of new electronic banking (eBanking) products such as automated teller machines (ATMs), cell phone banking (CB), and Internet banking (IB) into the marketplace significantly improves a financial institution's competitive position in a number of ways (Maenpaa, 2006). Firstly, the literature consistently illustrates that by successfully migrating their customers to eBanking channels, banking institutions will reduce expenses, and increase profitability (Berger, 2009; Berndt, Saunders and Petzer, 2010). Secondly, with banking innovations, financial institutions potentially can enhance the quality of service and banking experience in that their customers are liberated from banking within specific business hours at physical branches. In other words, customers 
can remotely access their accounts easily and conveniently from literally anywhere and anytime (Jayamaha, 2008). Thirdly, the banks' potential to reach a much wider pool of customers, over and above those accessible to the branch, including those in remote areas would be greatly improved; and thereby contributing significantly to the socio-economic development especially in developing countries such as Bangladesh. For these reasons, research into the acceptance and usage patterns of banking innovations has, over the years, proved to be not only an interesting subject but also an essential element in formulating financial institutions' marketing strategy.

However, as many bank marketing specialists including Black et al. (2001) have noted, the vast majority of products and (including banking) services which are launched annually fail at considerable cost to 'innovating' businesses. Particularly in the banking sector, the failure rate and low adoption rates of many innovations negatively impact on many financial services providers. Of note, IB is a typical innovation that potentially can transform the banking landscape in developing nations such as Bangladesh, but due to the associated low adoption rate, its full potential in deepening and extending banking services is yet to be realised. Although the popularity of the Internet, among Asian continues to grow, uptake of IB, on the other hand, still remains comparatively low (Berndt et al., 2010; Shambare, 2011). Thus, a better understanding of why some customers adopt IB and others do not, alongside an identification of the factors that may influence this decision is likely to be of considerable practical as well as academic value. It is for this reason that the purpose of this study is specifically to investigate the factors influencing the adoption and usage patterns of Internet banking. The rest of the paper is structured as follows: the following section discusses IB in Bangladesh. Next, the IB banking adoption framework is presented. The methodology and findings sections are presented followed by the discussion of results and concluding remarks.

\section{ReseARch Question}

Although the advantages of IB are well-documented in the literature - convenience, anytime-anywhere banking, privacy, and saving time (Brown, Cajee, Davies and Stroebel, 2003). In reality though these advantages for both consumers and service providers can only be realised when consumers adopt and use the service (Agarwal and Prasad, 1998), which at this point in time appears to be low. Consequently, the research questions for the study are formulated as follows:

RQ: What are most important factors affecting Internet banking adoption?

\section{LITERATURE REVIEW}

Bangladesh Bank is still reluctant to use full internet base banking activities. Compared to private and foreign banks, nationalized commercial banks are far behind implementing internet banking system in banking transactions. Nationalized commercial banks provide ATM services with very few branches and also the computerized branches are very small except the foreign commercial banking (Alam 2007). Internet Banking is growing popular day by day in Bangladesh. A number of private as well as local banks are going online now considering the demand and necessity of fast banking. People throughout the world are now getting engaged with more activity and business and hence need the fast and anytime access to his/her bank account. Internet banking also facilitates buying and selling various products which varies country to country. In Bangladesh many banks have launched Internet Banking. Amongst those HSBC, DBBL, City Bank, BRAC Bank, Bank 
Asia, Jamuna Bank, Janata Bank, Southeast Bank, AB Bank, First Security Bank, Mercantile Bank, Premier Bank etc are in action already. Some are known as online banking, some are Internet Banking, providing various facilities (BankInfo 2011).

Internet banking refers to a banking channel in which customers use the Internet to access their bank accounts and perform various functions including inter-account transfer, thirdparty payment, and checking balances. Customers use personal computers (or sometimes mobile devices - iPads or Smart phones) to connect to the Internet. For added security, IB websites are password protected - requiring intricate combinations of passwords and personal identification (PIN) codes. So, customers key-in their personal passwords in order to be allowed access to their accounts.

In Bangladesh, most of the Private commercial banks offer Internet banking services. Also, as expected in a maturing market, Bangladeshi banks offer similar IB services including online access to the account and checking balances. Only few banks offer inter-account transfers, purchases, bill payment, third-party payments and international online purchase. Because of the lack of scientific research in the area, the accuracy of these statistics is rather difficult to ascertain. Also as a result of the paucity of research, there is no clear sense of the state of IB in Bangladesh. Thus, bank marketers seem to grapple with formulating effective marketing strategies since all that is known about IB adoption is learnt from the West. For that reason, this study attempts to fill the gap in the literature by studying factors influencing the adoption of IB in Bangladesh.

\section{CONCEPTUAL DimENSIONS OF IB}

The literature identifies numerous conceptual frames modelling consumer adoption of new technologies including Internet banking. The most cited ones are the Technology Acceptance Model (TAM) (Davis, 1989), the Innovation Diffusion Theory (IDT) (Rogers, 1995), the Theory of Reasoned Action (TRA) (Taylor and Todd, 1995), and the Theory of Planned Behaviour (TPB) (Ajzen, 1991). Of these, past studies have consistently demonstrated that consumer perceptions, in particular, Rogers' (1995) IDT was the most reliable predictor of adoption of new innovations. This model has been tested and widely applied in numerous settings including education, psychology, and marketing (Agarwal and Prasad, 1998; Meuter, Bitner, A.L and Brown, 2005; Robertson, 1967; Rogers, 1983; Shivers-Blackwell and Charles, 2006; Taylor and Todd, 1995). The IDT model presupposes that adoption of new innovations is influenced by potential adopters' perceptions towards the characteristics of the innovation. In total, five characteristics associated with new innovations are identified. These are relative advantage, compatibility, and complexity, observability, and trialability, which are identified as "the most important characteristics of innovations in explaining the rate of adoption" (Rogers, 1995:16). Thus, innovations that are perceived by individuals as having greater relative advantage, compatibility, trialability, and less complexity will be adopted more rapidly than other innovations. The innovation characteristics are defined next.

\section{Relative Advantage}

Is the additional benefit that an innovation has relative to another method is positively related to its rate of adoption. It is therefore possible to suggest that the advantages that Internet banking offers over other banking methods would affect its rate of adoption. Among these advantages are anytime and anywhere banking that is convenient, since 
banking customers can access their accounts using their cell phones. The following hypothesis was, as a result, formulated:

$\mathrm{H}_{1}$ : the greater the perceived relative advantage of using $I B$, the more likely that it will be adopted.

Perceived compatibility: - refers to how well a technology fits with an individual's work, lifestyle, values, and needs (Rogers, 1995). In the context of IB, compatibility is the extent to which the product is in line with how the customers live their lives. For example, customers who use the Internet more frequently and for numerous functions in their work and lives, they have a higher degree of compatibility with the Internet. Likewise, they are likely to have a greater chance of adopting Internet banking.

$\mathbf{H}_{2}$ : the greater the perceived compatibility of using $I B$, the more likely that it will be adopted.

Perceived complexity: - or the level of difficulty of using an innovation is inversely related to its adoption (Meuter et al., 2005; Taylor and Todd, 1995). This means that the greater the perceived complexity of conducting banking via the Internet, the less likely its adoption will be, and accordingly:

$\mathbf{H}_{3}$ : the greater the perceived complexity of using IB, the less likely that it will be adopted.

Trialability: - Potential adopters who are allowed to try out and experiment with an innovation prior to purchase are likely to get a first-hand feel of the product. Also, they have a greater chance of feeling comfortable with the technology, and thus are more likely to adopt it (Agarwal and Prasad, 1998). Thus, the adoption of Internet banking is more likely if the technology together with its benefit is demonstrated to users.

$\mathbf{H}_{4}$ : the greater the trialability of using $I B$, the more likely that it will be adopted.

Perceived risk: One of the major influencing factors around the establishment and use of new technologies for financial transactions is that of security and trust (Ho and $\mathrm{Ng}, 1994$ ). The need for security of personal details and financial information is therefore critical to the success of IB. Some of the risks associated with IB and banking, in general, are the possibility of losing money to fraud or loss of privacy. As a result, the lower the perception of risk involved in using cell phone banking, the more likely that it will be adopted.

$H_{5}$ : the greater the perceived risk of using $I B$, the less likely that it will be adopted.

Self-efficacy: refers to the confidence potential adopters have in their ability to use a specific technology (Bandura, 1982). Thus, it is reasonable to expect that the higher the Internet experience and skill possessed by individuals, the more likely they will be adopt IB.

$\mathbf{H}_{6}$ : the greater the self-efficacy of using $I B$, the more that it will be adopted.

Facilitating conditions (technology support): This construct may be interpreted to include support from both the Internet service providers as well as from the banks (Brown et al., 2003). Thus, IB will more likely be adopted if the technological backbone as well as its support is reliable.

Although Rogers (1995) identifies five key predictors of adoption, recent studies confirm that three of these: relative advantage, compatibility, and complexity have consistently proved to be stable predictors across multiple disciplines (Rugimbana, 1998).

$\mathbf{H}_{7}$ : the greater the perceived complexity of using $C B$, the less likely that it will be adopted. 
Adoption related studies show that consumers show high levels of resistance to trying new innovations. However, once this barrier of getting customers to try out a new product, adoption will most likely take place. For that reason, in this study, adoption was operationalised by whether respondents had indeed tried using IB or not. Accordingly, trial was measured using a single-item question assessing whether or not respondents had tried using IB.

\section{Research Methodology}

A cross-section survey method was used (Calder, Phillips and Tybout, 1981). Data were collected using self-completion questionnaires. Using convenience sampling, three research assistants distributed questionnaires at Boshundhara City Centre shopping mall in Dhaka. The completed questionnaires were checked for completeness; those with more than four missing values were discarded. SPSS was used for data analysis (Field, 2009).

\section{SAMPLE}

Since the study was concerned with banking customers, all individuals with a bank account potentially constituted the sampling frame. However, the study concentrated on young consumers, particularly under 40 years old. But, given the unknown bounds of such a sampling frame - under 40 years old and having a bank account - probabilistic sampling techniques were considered impractical to execute, hence the use of convenience sampling. Some 500 questionnaire were distributed; 373 were returned. Of these only 249 were fully completed and usable for data analysis, representing a response rate of about 67 per cent. More females (56 per cent) participated. Table 1 provides further details pertaining to the participants' demographic characteristics.

Table 1: Demographic Profile

\begin{tabular}{lll}
\hline Demographic Characteristics & Percentage \\
\hline Gender & Male & 44 \\
& Female & 56 \\
Age Group & $<20$ years & 5 \\
& $21-24$ years & 6 \\
& $25-29$ years & 48 \\
& 30 years & 41 \\
\multirow{5}{*}{ Employment Status } & Full-time employed & 87 \\
& Part-time employed & 5 \\
\multirow{5}{*}{ Education } & Students & 8 \\
& Diploma & 10 \\
\multirow{5}{*}{ Monthly Income } & Undergraduate & 4 \\
& Postgraduate & 86 \\
& < BDT 30, 000 & 84 \\
& BDT 30, 000-BDT 50,000 & 9 \\
& BDT 50,000-BDT 1,00,000 & 3 \\
& BDT 1,00,000+ & 4 \\
\hline
\end{tabular}




\section{RESULTS AND DISCUSSION}

\section{User Experience of the Internet}

In terms of Internet familiarity, approximately 65 per cent of the respondents indicated that they have used the Internet for up to three years, and almost 35 per cent reported having used the Internet for four years or more (Figure 1). Closer inspection revealed that only six respondents had never used the Internet at all, thus suggesting that Internet experience within the sample was moderate to high. The latter confirms findings of past research; in particular Black et al. (2001), who argued that Internet usage is growing rapidly.

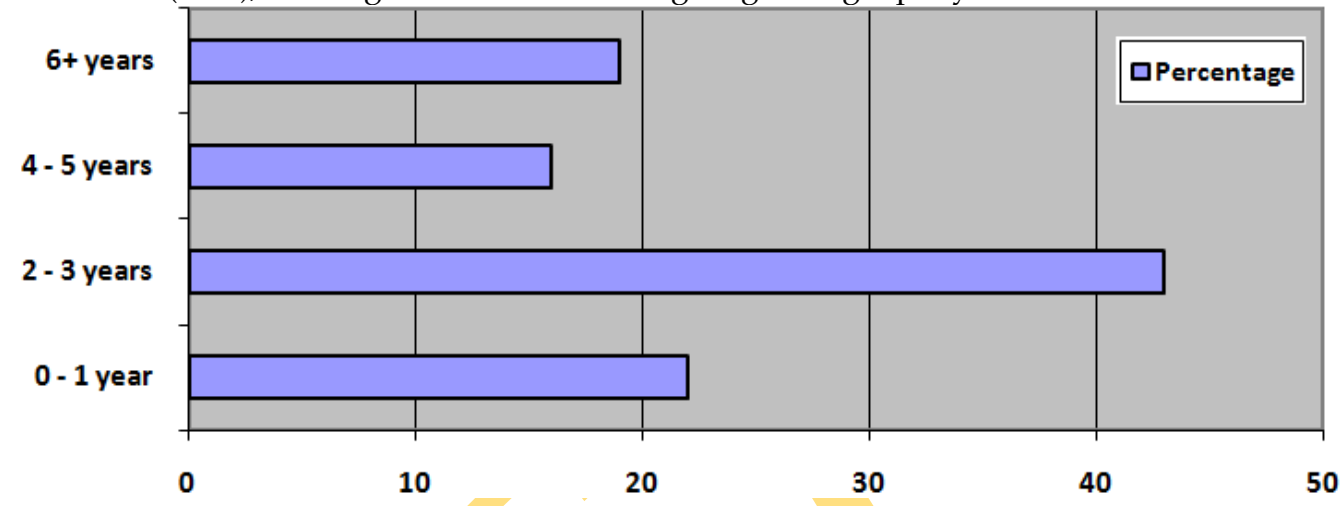

Figure 1: User experience of Internet banking

\section{INTERNET BANKING}

It was also insightful to ascertain the factors influencing the adoption of Internet banking. The 20-item scale was used to determine which factors influenced Internet banking adoption. According to the conceptual frame, the seven factors or sub-scales determined consumers' acceptance of IB and ideally should load independently as distinct factors. To test these factors, Principal Component Analysis (PCA) was conducted on the 20 items (Malholtra, 2010).

The factorability statistics were satisfactory $\left(\mathrm{KMO}=0.724\right.$; Bartlett's Test of Sphericity $X^{2}=$ 1161.709; $d f=190 ; p<0.000)$. A six-factor solution, accounting for 67 per cent of variance, was extracted (Table 2). With the exception for complexity and technology support, the remaining four factors had Cronbach's alphas of greater than the common minimum of 7 (Field, 2009). However, since these were greater than .5, which is considered as absolute minimum for exploratory research, these were considered acceptable.

Table 2: Six-item solution of the IB factors

\begin{tabular}{llcc}
\hline Factor & Sub-scale(s) & Eigenvalues & $\begin{array}{c}\text { Cronbach's } \\
\text { alpha }(\boldsymbol{\alpha})\end{array}$ \\
1 & Self-efficacy \& Trialability & 4.258 & .787 \\
2 & Risk & 2.561 & .775 \\
3 & Complexity & 1.745 & .594 \\
4 & Compatibility & 1.589 & .709 \\
5 & Relative advantage & 1.358 & .703 \\
6 & Technology Support & 1.190 & .620 \\
\hline
\end{tabular}




\section{Conclusions}

The findings of this study suggest that the Internet is a very popular technology, and is largely widely accepted by young Bangladeshi consumers, as Internet adoption ranges from moderate to high experience. Overall, the data found support for all the tested hypotheses, indicating that the seven factors (self-efficacy, trialability, risk, complexity, compatibility, relative advantage, and technology support) are important determinants of IB adoption. The fact that self-efficacy and trialability loaded onto a single factor indicates the general influence of consumers' perceptions of their ability to use IB services. This ties in very closely with the arguments by Meuter et al (2005) that getting customers to feel comfortable about a technological innovation is achieved by having them try the innovation first. Thus, this paper reinforces previous findings, which suggest perceived attributes of innovations are important in predicting its acceptance and usage.

Future researchers could consider studying consumer choice behaviour of numerous other banking technologies including ATMs, credit cards, or mobile banking. The use of a different consumer segment, for instance the elderly or women might also provide unique insights into the phenomenon.

\section{REFERENCES}

Alam, S. H. And Others (2007). "Developments and prospects of internet banking in Bangladesh." International Business Journal, Vol 17, No 1/2: 56-66.

Agarwal, R. and Prasad, J. (1998). "The antecedents and consequents of user perceptions in information technology adoption." Decision Support Systems, 22 (1998): 15-29.

Ajzen, I. (1991). "The Theory of Planned Behaviour." Organizational Behavior and Human Decision Processes, 50: 179-211.

Bandura, A. (1982). "Self-efficacy mechanism in human agency." American Psychologist, 37(2): 122147.

Berger, S. (2009). "Self-service technology for sales purposes in branch banking: The impact of personality and relationship on customer adoption." International Journal of Bank Marketing, 27(7): 488-505.

Berndt, A. D., Saunders, S. G. and Petzer, D. J. (2010). "Readiness for banking technologies in developing countries." Southern African Business Review, 14(3): 47-76.

Black, N. J., Lockett, A., Winklhofer, H. and Ennew, C. (2001). "The adoption of Internet financial services: a qualitative study." International Journal of Retail \& Distribution Management, 29(8): 390-398.

Blumberg, B., Cooper, D. R. and Schindler, P. S. (2011). Business Research Methods, 3rd European Edition. London, McGraw Hill.

Brown, I., Cajee, Z., Davies, D. and Stroebel, S. (2003). "Cell phone banking: predictors of adoption in South Africa - an exploratory study." International Journal of Information Management, 23: 381-394.

Calder, B. J., Phillips, L. W. and Tybout, A. M. (1981). "Designing Research for Application." Journal of Consumer Research, 8(2): 197-207.

Davis, D. (1989). "Perceived Usefulness, Perceived Ease of Use, and User Acceptance of Information Technology." MIS Quarterly, 13(3): 319-340.

Field, A. (2009). Discovering Statistics Using SPSS, 3rd Edition. Thousand Oaks, CA, Sage.

Ho, S. S. M. and Ng, V. T. F. (1994). "Risk Perceptions of Electronic Payment Systems." International Journal of Bank Marketing, 12(8): 26-38.

Maenpaa, K. (2006). "Clustering the consumers on the basis of their perceptions of the Internet banking services." Internet Research, 16(3): 304-322.

Malholtra, N. (2010). Marketing Research: An Applied Orientation, 6th Edition. Upper Saddle River, NJ, Pearson. 
Engineering International, Volume 1, No 2 (2013)

Meuter, M. L., Bitner, M. J., A.L, O. and Brown, S. W. (2005). "Choosing among alternative service delivery modes: an investigation of customer trial of self-service." Journal of Marketing, 69 (April 2005): 61-83.

Robertson, T. (1967). "The process of innovation and the diffusion of innovations." The Journal of Marketing, 31(1): 14.

Rogers, E. (1983). The Diffusion of Innovations, 3rd Edition. New York, The Free Press.

Rogers, E. (1995). Diffusion of Innovations, 4th edition. New York, The Free Press.

Rugimbana, R. (1998). Values, Perceptions, and Consumer Preference Patterns for Personal Banking Technologies in Australia and Malaysia, MacQuarie University. PhD Marketing.

Shambare, R. (2011). "Cell phone banking adoption in South Africa." Business and Economic Research, 1(1).

Shivers-Blackwell, S. L. and Charles, A. C. (2006). "Ready, set, go: examining student readiness to use ERP technology." Journal of Management Development, 25(8): 795-805.

South African Reserve Bank (2008). Annual Report: Bank Supervision Department. Pretoria, RSA, South African Reserve Bank.

Taylor, S. and Todd, P. (1995). "Decomposed and crossover effects in the theory of planned behaviour: A study of consumer adoption intentions." International Journal of Research in Marketing, 12(1995): 137-155.

Website: Bank Info: http://bankinfobd.com/blog/internet-banking-in-bangladesh

Asian Business Consortium is an independent research house committed to publishing and delivering superior, Peer-reviewed standard research 